\title{
Prevalence of Anemia in Children Three to 12 Months Old in a Health Service in Ribeirão Preto, SP, Brazil
}

\author{
Márcia Cristina Guerreiro dos Reis ${ }^{1}$ \\ Ana Márcia Spanó Nakano² \\ Isília Aparecida Silva ${ }^{3}$ \\ Flávia Azevedo Gomes ${ }^{4}$ \\ Maria José Bistafa Pereira ${ }^{5}$
}

\begin{abstract}
Iron deficiency anemia is the most common nutritional deficiency among children. This crosssectional, descriptive and quantitative study is part of a multicenter project, which verified the prevalence of anemia in children aged three to 12 months, treated by a health service unit in Ribeirão Preto, SP, Brazil. Interviews with mothers and determining hemoglobin dosage were carried out with 121 children who participated in the study. Two international criteria were adopted as parameters of anemia according to the children's age. Descriptive statistics, measures of central tendency and associations were used for data analysis. The prevalence of anemia among 69 children aged three to 5 months was $20.2 \%$ and $48.0 \%$ among 52 children aged six to 12 months. The total prevalence of anemia was $32.2 \%$. There was significant association between anemia and children's age, and anemia and the consumption of liquid cow's milk.
\end{abstract}

Descriptors: Anemia; Prevalence; Child Health (Public Health).

1 RN, M.Sc. in Nursing, Programa de Saúde da Criança, Secretaria Municipal de Saúde de Ribeirão Preto, SP, Brazil. E-mail: mguerreirodosreis@yahoo.com.br.

${ }^{2}$ RN, Ph.D. in Nursing, Associate Professor, Escola de Enfermagem de Ribeirão Preto, Universidade de São Paulo, WHO Collaborating Centre for Nursing Research Development, SP, Brazil. E-mail: nakano@eerp.usp.br.

${ }^{3}$ RN, Ph.D. in Nursing, Full Professor, Escola de Enfermagem, Universidade de São Paulo, SP, Brazil. E-mail: isasilva@usp.br.

${ }^{4}$ RN, Ph.D. in Nursing, Professor, Escola de Enfermagem de Ribeirão Preto, Universidade de São Paulo, Centro Colaborador da OMS para o Desenvolvimento da Pesquisa em Enfermagem, SP, Brazil. E-mail: flagomes@eerp.usp.br.

${ }^{5}$ RN, Ph.D. in Nursing, Associate Professor, Escola de Enfermagem de Ribeirão Preto, Universidade de São Paulo, WHO Collaborating Centre for Nursing Research Development, SP, Brazil. E-mail: zezebis@eerp.usp.br.

Corresponding Author:

Márcia Cristina Guerreiro dos Reis

Secretaria Municipal da Saúde de Ribeirão Preto

Rua Prudente de Morais, 457

Centro

CEP: 14015.100 Ribeirão Preto, SP, Brasil

E-mail: mguerreirodosreis@yahoo.com.br 


\section{Prevalência de anemia em crianças de 3 a 12 meses de vida em um serviço de saúde de Ribeirão Preto, SP, Brasil}

Das carências nutricionais entre crianças, a anemia ferropriva constitui-se no evento mais frequente. Este é um estudo transversal, descritivo, quantitativo, recorte de um projeto multicêntrico, que verificou a prevalência de anemia em crianças de 3 a 12 meses, em um serviço de saúde em Ribeirão Preto, SP. Foram realizadas entrevistas e dosagem de hemoglobina de 121 crianças que participaram do estudo. Adotaram-se dois critérios internacionais como parâmetros de anemia, de acordo com a idade da criança. Para a análise dos dados foram utilizadas estatística descritiva, medidas de tendência central e associações. A prevalência de anemia nas 69 crianças de 3 a 5 meses foi de $20,2 \%$ e naquelas 52, de 6 a 12 meses, foi de $48 \%$. A prevalência total de anemia foi de $32,2 \%$. Encontrou-se associação significativa entre anemia e idade da criança e anemia e uso de leite de vaca fluido.

Descritores: Anemia; Prevalência; Saúde da Criança.

\section{La prevalencia de anemia en niños de 3 a 12 meses de vida en un servicio de salud de Ribeirão Preto, SP, Brasil}

Entre las carencias nutricionales de niños, la anemia ferropénica es la más frecuente. Estudio transversal, descriptivo, cuantitativo es un extracto de un proyecto multicéntrico que verificó la prevalencia de anemia en niños de 3 a 12 meses de edad, en un servicio de salud de Ribeirão Preto, SP, Brasil. Fueron realizadas entrevistas y dosificación de hemoglobina en los 121 niños. Dos criterios internacionales fueron adoptados como parámetro de anemia, de acuerdo con la edad del niño. Estadística descriptiva, medidas de tendencia central y testes de asociación fueron usados para el análisis de datos. La prevalencia de anemia en los 69 niños de 3 a 5 meses fue del 20,2\%, y en los 52 niños de 6 a 12 meses fue del 48,0\%. En total, la prevalencia de anemia fue del 32,2\%. Encontró asociación significativa entre anemia y edad del niño y anemia y el consumo de leche de vaca liquido.

Descriptores: Anemia; Prevalencia; Salud del Niño.

\section{Introduction}

Anemia is defined by the World Health Organization as a condition in which the content of hemoglobin in the blood is below normal levels for a given age, gender and physiological condition due to a deficiency of one or more essential nutrients, among them iron, folic acid, zinc, vitamin B12 and proteins ${ }^{(1)}$.

According to the United Nations Children's Fund, 90\% of all types of anemia in the world are due to deficiency of iron. Anemia in Latin and Central America is caused by a deficiency of iron, which has been characterized as a severe public health problem, affecting approximately $50 \%$ of pregnant women and children ${ }^{(2)}$.

Studies addressing the prevalence of anemia in developing countries, as in the case of Brazil, and in low-income populations have been recommended(3).

There is no national data in Brazil describing the prevalence of iron deficiency anemia, though studies carried out in several regions in the country have shown a significant increase of the prevalence and severity of iron deficiency anemia in risk groups in recent years ${ }^{(2,4)}$. Regional data were obtained by a systematic review addressing the prevalence of anemia in Brazil in studies published between 1996 and 2007. More studies were developed in the Southeast geographic region than in other regions, though the North and Midwest, the least investigated regions, presented a high prevalence of 
anemia: more than half of the studied children presented the disease ${ }^{(5)}$. Its prevalence varies from $22.7 \%$ to $77.0 \%$ in the different regions and these discrepancies are related to socioeconomic factors ${ }^{(4)}$.

The causes of iron deficiency anemia may begin in the intra-uterine period due to a deficiency in the mother, since the physiological reserves of iron in the fetus are formed in the last period of pregnancy. This reserve jointly with iron acquired from maternal milk supports the infant's needs up to the sixth month of life.

The problem is aggravated in early childhood due to incorrect feeding habits, especially during weaning, when, maternal milk is frequently replaced by food that is poor in iron. Cow's milk is an example. Despite the fact it presents the same level of iron as maternal milk, its bioavailability is $\operatorname{low}^{(6)}$. The quantity of iron in maternal milk is 0.1 to $1.6 \mathrm{mg} / \mathrm{L}$ with high bioavailability, which enables the infant's system to absorb high levels of iron, reaching about $50 \%$ to $70 \%$ of it. This process is optimized by the presence of lactose, which participates in the mechanisms of calcium and iron absorption, a fact that has reinforced the evidence that maternal milk is one of the most important sources of protection against anemia in infants ${ }^{(7)}$. Maternal nutrient deficiency during lactation may reduce the concentration of some of these nutrients in maternal milk with consequent depletion in the child. Coupled with this, iron absorption from maternal milk diminishes up to $80 \%$ when other foods begin to be consumed(8).

Therefore, we propose an investigation to address anemia in children three to 12 months of age in a health unit of Ribeirão Preto, SP, Brazil. This study is part of a multicenter ${ }^{(9)}$ study in which three cities in the Brazilian southeast region participated: Ribeirão PretoSP; São Paulo-SP and Rio de Janeiro-RJ. The results of this study will contribute to other studies and support the improvement of actions and protocols directed to childcare and follow-up in health services.

The objective was to verify the prevalence of anemia in children aged three to 12 months associated with variables for children's: age, gender, weight at birth, gestational age, use of iron supplementation, hemoglobin value $(\mathrm{Hb})$ at the day of collection in a health service in Ribeirão Preto.

\section{Material and Method}

This is a cross-sectional, observational, descriptive and quantitative study. Three health services were included in the overall study: BHU Vila Virginia, Ribeirão
Preto-SP; The Health Center School in Butantã, São Paulo-SP, and the pediatric outpatient clinic in the Institute Fernandes Figueira, Rio de Janeiro, RJ, Brazil.

The multicenter project and this study were approved by Ethics Research Committee at the University of São Paulo at Ribeirão Preto, College of Nursing, protocols n' 342/2003 and 0538/2005 - CEP-EEUSP respectively, in compliance with Resolution 196/96 of the National Health Council.

Data were collected in the Basic Health Unit (BHU) in Vila Virginia, in Ribeirão Preto-SP, which is located in the south area of the city and was chosen because it presents one of the highest rates of live birth in the city. Other factors such as the significant increase in exclusive breastfeeding rates in children younger than four months of age and the systematization of actions to promote breastfeeding were also relevant to this choice.

Data were collected from December $1^{\text {st }} 2005$ to July $30^{\text {th }} 2006$. Study participants were mothers who agreed to participate in the study and their children aged three to 12 months (incomplete) with appointments scheduled in the pediatric service of the BHU Vila Virginia, Monday through Friday in the afternoon, according to inclusion and exclusion criteria.

Inclusion criteria included: children aged three to 12 months (incomplete), from any ethnic group and social class with appointments scheduled in the unit in the afternoon and who were accompanied by their mothers.

Exclusion criteria: children with no medical file in the unit; or with an acute infectious condition at the day of the interview; or who were cared for in the pediatric emergency care unit.

The age limits between three to 12 months of age were established due to the fact that the concentration of hemoglobin reaches the lowest value observed in the child's entire developmental period because of the transformation of fetal hemoglobin to adult hemoglobin that occurs in the first two months of life, which is referred to as "physiologic anemia of infancy"(2). The influence of breastfeeding on anemia is better verified in children younger than six months of age, and it is not predictive of iron deficiency after this period ${ }^{(10)}$. However, we consider it important to analyze the prevalence of anemia among children six to 12 months of age since this is a period in which children's diet is changed, that is, it is a critical stage, which can frequently lead to the disease when the child does not receive an appropriate $\operatorname{diet}^{(11)}$. 
The following variables were considered for the study's descriptive analysis: maternal variables - age, schooling, number of children and occupation; and children's variables - age, gender, weight at birth, gestational age, iron supplementation, hemoglobin value $(\mathrm{Hb})$ at the day of collection. Two criteria were used as indicators of anemia: $\mathrm{Hb}<10.3 \mathrm{~g} / \mathrm{dl}$ (Saarinen's standard) ${ }^{(12)}$ for children younger than six months of age and $\mathrm{Hb}<11.0 \mathrm{~g} / \mathrm{dl}$ (WHO standard) ${ }^{(13)}$ for children aged six to 12 months. Other studied variables were related to families' life style and housing: type of housing, basic sanitation and variables related to breastfeeding and liquid feeding. The categories proposed by $\mathrm{PAHO} / \mathrm{WHO}^{(14)}$ were used to classify breastfeeding and the categories Weaning (W) and Never Breastfed (NB) were included.

Exclusive Breastfeeding (EB): the child receives only maternal milk directly from the breast or extracted from it and no other liquid or solid food, with the exception of medication or vitamin supplements; Predominant Breastfeeding (PB): the child receives breast milk and also water or water-based beverages (teas, juices) and no other liquid or solid food; Breastfeeding (B): the child receives breast milk regardless of any other liquid or solid foods, including other types of milk; Weaning (W): the child does not receive breast milk, but other types of milk, liquid or solid foods are offered; Never Breastfed (NB): the child never received breast milk.

The presence or absence of anemia, categorized by the two mentioned international standards according to age, was considered the dependent variable in the association analysis and the independent variables were those related to the children and their diet focusing on the types of breastfeeding, types of formulas, use of water and tea.

Interviews with the mothers to complete the form and blood collection from the children occurred after medical consultation. Blood samples were collected from the children's calcaneous to dose hemoglobin $(\mathrm{Hb})$, a procedure performed with a portable photometer $\left(\right.$ HemoCue $^{\mathrm{R}}$ ) for the direct and immediate reading of samples. This equipment is recommended in population investigations to verify the prevalence of anemia. A small quantity of non-diluted blood is used; it promotes a smaller risk of errors and presents immediate results ${ }^{(15)}$. The hemoglobin value was disclosed to mothers and recorded on the children's medical files so measures were taken to diagnose and treat anemia if necessary.

Statistical analysis was performed using the Statistical Package for Social Sciences (SPSS ${ }^{\circledR}$, version 11.5). Central tendency measures were used for continuous quantitative variables: average, standard deviation, median, minimum and maximum values. Chisquare and Fisher's exact test with level of significance $\alpha=0.05$ were used to associate anemia and children's variables and diet.

\section{Results}

A total of 121 mothers were interviewed. The majority $(93 ; 76.6 \%)$ lived with their partners; 90 (74.6\%) were housewives. The age of the mothers varied from 15 to 41 years old, with an average of $25.5(\mathrm{sd}=6.4)$ and median of 24 years. In regard to schooling, 66 (54.5\%) had primary school (incomplete or complete); 2 (1.7\%) were illiterate and three $(2.5 \%)$ had a bachelor's degree. The average age of the children was $1.9 ; 56$ (46.3\%) were primiparous. The majority of families, 113 (93.4\%), lived in masonry houses, while 55 (45.5\%) lived in their own houses; $100 \%$ were connected to electricity; $95 \%$ had a water connection; and $99.2 \%$ had garbage collection. The majority of families $(71 ; 58.7 \%)$ lived with four people and one or two family members contributed to the family income $(80.2 \%)$.

In regard to the 121 children, 66 (54.5\%) were male; $110(91.0 \%)$ born at term; 69 (57.0\%) were younger than six months, the average age was 189.9 days ( $s d=80.3$ ) and the median was 169 days. The lowest weight at birth was 2,020 grams, the highest was 4,165 grams and the average was $3,188.4$ grams ( $\mathrm{sd}=447.4$ ).

In relation to breastfeeding, $78(64.5 \%)$ where being breastfed on the day of the interview and 43 $(35.5 \%)$ were weaned, including two who were never breastfed. Among the 78 children, seven (9.0\%) were EB; $13(16.7 \%)$ were PB and $58(74.3 \%)$ were B. Seven $(10.1 \%)$ out of the $69(100.0 \%)$ children younger than six months of age were EB, 11 children (16\%) were PB, $35(50.7 \%)$ were $B$, while 25 of these were in mixed breastfeeding, $15(21.7 \%)$ were weaned and one $(1.4 \%)$ was never breastfed.

Of the $52(100.0 \%)$ children older than six months of age, two (3.8\%) were PB, 23 (44.2\%) were B and 15 of these were in mixed feeding (eight children received liquid cow's milk and seven dried cow's milk), eight were B; 27 (52\%) were weaned and one of them was never breastfed.

For the total of 121 children, the average duration of EB was 81.1 days ( $\mathrm{sd}=52.5$ ) and the median was 90 days. For the total of 78 children who were being breastfed, the average duration of $B$ was 170.7 days (5.7 months) and the median was 151.5 days ( 5 months).

As for artificial feeding, whether by the consumption of liquid and/or dried cow's milk, 19 (27.5\%) and 23 
(33.3\%) out of the total of 69 children younger than six months of age were receiving liquid and dried cow's milk respectively. The consumption of liquid cow's milk increased to $61.5 \%$ in children older than six months of age, while the consumption of dried milk diminished to $23.1 \%$. The consumption of water and/or tea was $82.6 \%$ for the 69 children younger than six months.

Of the total of 121 children aged three to 12 months (incomplete) distributed according to age and the hemoglobin value measured at the time of data collection, average value and median of hemoglobin was $11.1 \mathrm{~g} / \mathrm{dL}$; standard deviation was 1.41 . The lowest value of hemoglobin found was 7.3 and the highest was $15.4 \mathrm{~g} / \mathrm{dL}$.

Tables 1 and 2 present the distribution of children aged three to 12 months (incomplete) according to age and anemia criteria. For the total of 69 (100\%) children aged three to 5 months (incomplete), the prevalence of anemia was $20.2 \%$ (14) (Table 1 ). For children aged six to 12 months (incomplete), $(n=52)$ the prevalence of anemia was $48.0 \%$, based on the WHO criteria (Table 2 ).

Table 1 - Distribution of children aged three to 5 months old*, cared for in the pediatric service of the BHU Vila Virginia, in the afternoon, according to international standards for anemia, from September 2005 to July 2005, Ribeirão Preto, SP, Brazil

\begin{tabular}{|c|c|c|c|c|c|c|}
\hline \multicolumn{7}{|c|}{ Anemia (Saarinen's standard)** } \\
\hline \multirow{2}{*}{$\begin{array}{c}\text { Age } \\
\text { (months)* }\end{array}$} & \multicolumn{2}{|c|}{ Yes } & \multicolumn{2}{|c|}{ No } & \multicolumn{2}{|c|}{ Total } \\
\hline & $\mathrm{n}$ & $\%$ & $\mathbf{n}$ & $\%$ & $\mathbf{n}$ & $\%$ \\
\hline 3 & 8 & 33.3 & 16 & 66.7 & 24 & 34.8 \\
\hline 4 & 5 & 20 & 20 & 80 & 25 & 36.2 \\
\hline 5 & 1 & 5 & 19 & 95 & 20 & 29 \\
\hline Total & 14 & 20.2 & 55 & 79.8 & 69 & 100 \\
\hline
\end{tabular}

*age in complete months +29 days. **Saarinen's standard, et al, 1868 . $\mathrm{Hb}<10.3 \mathrm{~g} / \mathrm{dl} ;<6$ months old.
Of the total of 121 children aged three to 12 months, the prevalence of anemia was $32.2 \%$ (29) based on Saarinen's standard for children younger than six months of age (Table 1) and WHO standard for children older than six months of age (Table 2).

Table 2 - Distribution of children aged six to 12 months (incomplete), cared for in the childcare service of the BHU Vila Virginia, in the afternoon, in relation to international standards of anemia, from September 2005 to July 2006, Ribeirão Preto, SP, Brazil

\begin{tabular}{|c|c|c|c|c|c|c|}
\hline \multicolumn{7}{|c|}{ Anemia (WHO standard) ${ }^{* *}$} \\
\hline \multirow{2}{*}{$\begin{array}{c}\text { Age } \\
\text { (months)* }\end{array}$} & \multicolumn{2}{|c|}{ Yes } & \multicolumn{2}{|c|}{ No } & \multicolumn{2}{|c|}{ Total } \\
\hline & $\mathrm{n}$ & $\%$ & $\mathbf{n}$ & $\%$ & $\mathbf{n}$ & $\%$ \\
\hline 6 & 7 & 50 & 7 & 50 & 14 & 27 \\
\hline 7 & 3 & 50 & 3 & 50 & 6 & 11.5 \\
\hline 8 & 4 & 57 & 3 & 42.9 & 7 & 13.5 \\
\hline 9 & 3 & 42.9 & 4 & 57.1 & 7 & 13.5 \\
\hline 10 & 2 & 28.6 & 5 & 71.4 & 7 & 13.5 \\
\hline 11 & 6 & 54.5 & 5 & 45.5 & 11 & 21 \\
\hline Total & 25 & 48 & 27 & 52 & 52 & 100 \\
\hline
\end{tabular}

*age in complete months +29 days. **WHO standard, et al, $1868 . \mathrm{Hb}<$ $11.0 \mathrm{~g} / \mathrm{dl} ;>6$ months old.

No statistical association was found between anemia and children's variables in the bivariate analysis: gender, weight at birth, gestational age and iron supplementation. However, we observed a higher of prevalence of anemia among male children (34.8\%), among those whose weight at birth was above or equal to 2,500 grams $(32.4 \%)$, those whose gestational age was above 37 weeks (32.7\%) and among those who did not take iron supplements (Table 3 ). There was a strong association between anemia and children older than six months of age (complete) $\left(x^{2}=10.48\right.$, $\mathrm{p}<0.001$ ).

Table 3 - Distribution of children's variables (age, weight at birth, gestational age, iron supplement) associated with anemia (Saarinen's and WHO standards) for children aged three to 12 months (incomplete), cared for in the childcare service of the BHU Vila Virginia, in the afternoon, from September 2005 to July 2006, , Ribeirão Preto, SP, Brazil

\begin{tabular}{|c|c|c|c|c|c|c|}
\hline \multicolumn{7}{|c|}{ Anemia (Saarinen and WHO standards) } \\
\hline \multirow{2}{*}{ Children's variables } & \multicolumn{2}{|c|}{ Yes } & \multicolumn{2}{|c|}{ No } & \multirow{2}{*}{$\begin{array}{c}\text { Total } \\
\mathrm{n}\end{array}$} & \multirow{2}{*}{$\mathbf{P}^{*}$} \\
\hline & $\mathbf{n}$ & $\%$ & $\mathrm{n}$ & $\%$ & & \\
\hline Age (months) & & & & & & 0.001 \\
\hline $3+6$ & 14 & 20.3 & 55 & 79.7 & 69 & \\
\hline $6+12$ & 25 & 48.1 & 27 & 51.9 & 52 & \\
\hline Total & 39 & 32.2 & 82 & 67.8 & & \\
\hline Gender & & & & & & 0.50 \\
\hline Male & 23 & 34.8 & 43 & 65.2 & 66 & \\
\hline Female & 16 & 29.1 & 39 & 70.9 & 55 & \\
\hline Total & 39 & 32.2 & 82 & 67.8 & 121 & \\
\hline
\end{tabular}


Table 3 - Continuation

\begin{tabular}{|c|c|c|c|c|c|c|}
\hline \multicolumn{7}{|c|}{ Anemia (Saarinen and WHO standards) } \\
\hline \multirow{2}{*}{ Children's variables } & \multicolumn{2}{|c|}{ Yes } & \multicolumn{2}{|c|}{ No } & \multirow{2}{*}{$\begin{array}{c}\text { Total } \\
\mathrm{n}\end{array}$} & \multirow{2}{*}{$\mathbf{P}^{*}$} \\
\hline & $\mathbf{n}$ & $\%$ & $\mathbf{n}$ & $\%$ & & \\
\hline Weight at birth (grams) & & & & & & 1.0 \\
\hline$<2500$ & 3 & 30 & 7 & 70 & 10 & \\
\hline$\geq 2500$ & 36 & 32.4 & 75 & 67.6 & 111 & \\
\hline Total & 39 & 32.2 & 82 & 67.8 & 121 & \\
\hline Gestational age & & & & & & 1.0 \\
\hline Pre-term & 3 & 27.3 & 8 & 72.7 & 11 & \\
\hline At term & 36 & 32.7 & 74 & 67.3 & 110 & \\
\hline Total & 39 & 32.2 & 82 & 67.8 & 121 & \\
\hline Iron supplement & & & & & & 0.66 \\
\hline Yes & 5 & 27.8 & 13 & 72.2 & 18 & \\
\hline No & 34 & 33 & 69 & 67 & 103 & \\
\hline Total & 39 & 32.2 & 82 & 67.8 & 121 & \\
\hline
\end{tabular}

*Statistically significant at $5 \%$ level of significance on the hypothesis that the causal effect is due to random sampling

There was no statistically significant association between anemia and breastfeeding, regardless of the type of breastfeeding, $\left(x^{2}=2.83, p=0.092\right)$ nor association between anemia and EB, or anemia and the use of water and/or tea (Table 4). There was statistically significant association between the use of liquid cow's milk and anemia $\left(x^{2}=6.68, p=0.010\right)$.

Table 4 - Distribution of variables breastfeeding/liquid feeding associated with anemia (Saarinen and WHO standards) in children aged three to 12 months (incomplete), cared for in the childcare service in the BHU Vila Virginia, in the afternoon, from September 2005 to July 2006, Ribeirão Preto, SP, Brazil

\begin{tabular}{|c|c|c|c|c|c|c|c|}
\hline \multicolumn{8}{|c|}{ Anemia (Saarinen and WHO standards) } \\
\hline \multirow{2}{*}{ Variables breastfeeding/ feeding } & \multicolumn{2}{|c|}{ Yes } & \multicolumn{2}{|c|}{ No } & \multicolumn{2}{|c|}{ Total } & \multirow{2}{*}{$\mathbf{P}^{*}$} \\
\hline & $\mathbf{n}$ & $\%$ & $\mathbf{n}$ & $\%$ & $\mathbf{n}$ & $\%$ & \\
\hline Breastfeeding & & & & & & & 0.092 \\
\hline Yes & 21 & 26.9 & 57 & 73.1 & 78 & 64.5 & \\
\hline No & 18 & 41.9 & 25 & 58.1 & 43 & 35.5 & \\
\hline Total & 39 & 32.2 & 82 & 67.8 & 121 & 100 & \\
\hline EB & & & & & & & 1.0 \\
\hline Yes & 2 & 28.6 & 5 & 71.4 & 7 & 9 & \\
\hline No & 19 & 26.8 & 52 & 73.2 & 71 & 91 & \\
\hline Total & 21 & 26.9 & 57 & 73.1 & 78 & 100 & \\
\hline Water-tea & & & & & & & 0.22 \\
\hline Yes & 37 & 34.3 & 71 & 65.7 & 108 & 89.3 & \\
\hline No & 2 & 15.4 & 11 & 84.6 & 13 & 10.7 & \\
\hline Total & 39 & 32.2 & 82 & 67.8 & 121 & 100 & \\
\hline Cow's milk & & & & & & & 0.010 \\
\hline Yes & 23 & 45.1 & 28 & 54.9 & 51 & 42.1 & \\
\hline No & 16 & 22.9 & 54 & 77.1 & 70 & 57.8 & \\
\hline Total & 39 & 32.2 & 82 & 67.8 & 121 & 100 & \\
\hline Dried milk & & & & & & & 0.159 \\
\hline Yes & 8 & 22.9 & 27 & 77 & 35 & 29 & \\
\hline No & 31 & 36 & 55 & 64 & 86 & 71 & \\
\hline Total & 39 & 32.2 & 82 & 67.8 & 121 & 100 & \\
\hline
\end{tabular}

*Statistically significant at $5 \%$ level of significance on the hypothesis that the causal effect is due to random sampling 


\section{Discussion}

The results refer to children cared for in a health unit from the Brazilian public network and do not reflect the epidemiological situation of anemia in children younger than one year of age in Ribeirão Preto, SP, Brazil. However, studies addressing the prevalence of anemia with representative samples of Brazilian cities have reported similar or even superior values to those found in this study ${ }^{(16)}$.

In this study, the prevalence of anemia in children aged three to 5 months (complete) was $20.2 \%$ regardless of the type of breastfeeding. In comparing it with the multicenter study carried out in the three studied cities, the prevalence of anemia was $21.6 \%$ according to the same standard for children younger than six months of age ${ }^{(9)}$. A study carried out in the state of São Paulo with children younger than six months of age, and in Pernambuco, showed a prevalence of anemia of $59.1 \%$ and $40 \%$ respectively(2).

There was an increase of anemia in the second semester of life: $50.0 \%$ at six months of age and $48.0 \%$ from six to 12 months (incomplete), which corroborates data available in the literature and the results obtained in the three cities from the multicenter study, which was $48.7 \%$ for children aged six to 12 months $^{(9,17)}$.

The prevalence of anemia in this study for the 121 children aged three to 12 months was $32.2 \%$ and when compared with data from the multicenter study, the value found was $35.1 \%(n=443)$ according to the same standards $^{(9)}$.

Birth conditions such as prematurity and low birthweight are described as risk factors relevant to anemia since smaller reserves of iron are available at birth and the early depletion of it lead to anemia(17). These associations were not significant in this study, perhaps due to the small number of children who presented such characteristics (10 presented low weight at birth and 11 were premature).

In relation to the use of an iron supplement, its consumption was not statistically significant in relation to the absence of anemia. Of the total of 52 children older than six years of age, 41 (78.8\%) did not use an iron supplement, unlike the remaining 11 (21.2\%) who did. This is a measure recommended by the Brazilian Society of Pediatrics and by the Ministry of Health(18).

Although the adoption of an appropriate diet contributes to the maintenance of appropriate iron nutritional levels during infancy, an additional source of iron during the first two years of age is essential, whether through medication supplements or fortification of foods. In places where the prevalence of anemia is high and the majority of foods consumed by infants are not fortified with iron, the recommendation is that iron supplements be a priority in the prevention of anemia(19-20).

A significant association between anemia and children's age was found. Thus, children older than six months of age were at a higher risk of acquiring anemia, which agrees with results from other $\operatorname{studies}^{(9,17)}$.

In relation to breastfeeding, we verified that the indicators found were below those recommended by the Ministry of Health and WHO. In the comparison with the multicenter study, in the three studied cities, the institution in Rio de Janeiro presented the highest rate of exclusively breastfed children (34.6\%) followed by São Paulo (15.6\%). On the other hand, predominant breastfeeding was highest among children in Ribeirão Preto $(16.7 \%)$ and lowest in Rio de Janeiro (1.5\%). We also observe in the three scenarios of the multicenter study that the duration of EB in children younger than four and six months diminished as they got older, as observed in national studies in the state of São Paulo and in Ribeirão Preto(21-22). Similar to this study, other studies did not find significant association between anemia, EB and $\mathrm{B}^{(9,20)}$.

The consumption of liquid cow's milk has been identified as one of the main determinants of anemia in the first year of life ${ }^{(16)}$. Corroborating another study ${ }^{(20)}$, we found a strong association between cow's milk and anemia $\left(x^{2}=6.68, p=0.010\right)$. Several studies agree with the findings of this study in relation to the early introduction of liquid cow's milk and hemoglobin below the recommended level. Casein and whey proteins from cow's milk, which constitute the protein fraction of the majority of infant formulas, and industrialized baby food negatively affect iron absorption, which is aggravated by the increased need for iron imposed by the rapid growth of children ${ }^{(23)}$.

Feeding habits have been evidenced as determinants closely related to anemia during infancy, among them: brief exclusive breastfeeding; consumption of cow's milk; late introduction and insufficient consumption of food sources of iron, as well as foods that facilitate its absorption.

\section{Conclusions}

The results of this study allowed determining that the prevalence of anemia in children aged three to 12 months, cared for in the childcare service in the $\mathrm{BHU}$ 
Vila Virginia, in the afternoon, varied according to the children's age and standard used to detect anemia: $20.2 \%$ of the 69 children aged three to 5 months and $48 \%$ for 52 children aged six to 12 months (incomplete). The prevalence of anemia in the 121 children aged three to 12 months was $32.2 \%$ according to the Saarinen's and WHO standards.

Statistically significant association was found between anemia and children's age and the consumption of liquid cow's milk. We draw attention to care provided to children in this age range in the prevention, diagnosis and treatment of this deficiency. Challenges and strengths are presented for the multi-professional team involved with childcare. Support for mothers/women concerning how to provide a diet appropriate for the growth and development of their children requires a synergistic relationship between technical efficiency and the proper use of relational technology in order to welcome, listen to and take co-responsibility with mothers/women. Nursing practice allows the development of these attributes, especially with women, to guide mothers/ women concerning their children's care.

\section{References}

1. World Health Organization. Global strategy for infant and young child feeding. Geneva; 2001.

2. Coutinho GGP, Bertollo EMG, Benelli ECP. Iron deficiency anemia in children: a challenge for public health and for society. Med J. (São Paulo). 2005; 123(2):88-92

3. Ailinger R, Moore JB, Pawloski L, Cortés LRZ. Concepts of anemia among low income Nicaraguan women. Rev. Latino-Am. Enfermagem. março-abril 2009; 17(2):147-52.

4. Miranda AS, Franceschini SCC, Priore SE, Euclides MP, Araújo RMA, Ribeiro SMR. Anemia ferropriva e estado nutricional de crianças de 12 a 60 meses no município deViçosa, MG. Rev Nutr. 2003; (2):163-9.

5. Jordão RE, Bernardi JLD, Barros AA Filho. Prevalência de anemia ferropriva no Brasil: uma revisão sistemática. Rev Paul Pediatria 2009; 27(1):90-8.

6. Rao R, Georgieff MK. Iron in fetal and neonatal nutrition. Semin Fetal \& Neonat Med. 2007; 12:54-63.

7. Almeida JSG, Novak F. O leite humano: qualidade e controle. In: Santos Jr (org) Fisiologia e patologia da lactação. Natal: Ed Sociedade Brasileira de Mastologia; 1995.

8. Allen LH. Multiple micronutrients in pregnancy and lactation: an overview. Am J Clin Nutr. 2005; 81 suppl:1206S-12S.

9. Reis MCG. Prevalência de anemia em crianças de 3 a 12 meses de vida em relação ao aleitamento materno, num serviço de saúde de Ribeirão Preto-SP. [dissertação]. Ribeirão Preto (SP): Escola de Enfermagem de Ribeirão Preto/USP; 2007.

10. Oliveira MAA, Osório MM. Consumo de leite de vaca e anemia ferropriva na infância. J Pediatr. 2005; 81(5):361-7.

11. Simon VGN, Souza JMP, Souza SB. Introdução de alimentos complementares e sua relação com variáveis demográficas e socioeconômicas, em crianças no primeiro ano de vida, nascidas em Hospital Universitário no município de São Paulo. Rev Bras Epidemiol. 2003; 6(1):29-38.
12. Saarinen UM, Siimes MA. Developmental changes in red blood cell counts and indices of infants after exclusion of iron deficiency by laboratory criteria and continuous iron supplementation. J Pediatr. 1978; 92:412-6. 13. World Health Organization. Iron deficiency anaemia. Assessment, prevention, and control. A guide for program managers. Geneva: Who/ Unicef/Unu; 2001.

14. Organización Panamericana de la Salud. Indicadores para evaluar las prácticas de lactáncia materna. Informe de una reunión. Ginebra; 1991.

15. Hudson-Thomas MA. Evaluation of the Hemocue for measuring hemoglobin in field studies in Jamaica. Bull WHO. 1994; 73(3):423-6. 16. Monteiro CA, Szarfarc SC, Mondini L. Tendência secular da anemia na infância na cidade de São Paulo (1984-1996). Rev Saúde Pública. 2000; 34:62-72.

17. Osório MM. Fatores determinantes da anemia em crianças. J Pediatr (Rio de Janeiro). 2002; 78940:269-78.

18. Ministério da Saúde (BR). Secretaria de Atenção à Saúde. Departamento de Atenção Básica. Manual operacional do Programa Nacional de Suplementação de Ferro. Brasília (DF): Ministério da Saúde; 2005.

19. Assunção MCF, Santos IS. Efeito da fortificação de alimentos com ferro sobre anemia em crianças: um estudo de revisão. Cad Saúde Pública. 2007; 23(2):269-81.

20. Silva DG, Priori SE, Franceschinni SC. Risk factors for anemia in infants assisted by public health services: the importance of feeding practices and iron supplementation. J Pediatr (Rio de Janeiro) 2007; 83(2):149-56.

21. Venâncio SI. Freqüência e determinantes do aleitamento materno em municípios do Estado de São Paulo. Rev Bras Epidemiol. 2002; 36(3)313-8.

22. Pereira MJB. Indicadores de aleitamento materno no município de Ribeirão Preto, SP. Rev Bras Epidemiol. 2004; 7(1):36-43.

23. Oliveira MA, Osório MM. Consumo de leite de vaca e anemia ferropriva na infância. J Pediatr (Rio de Janeiro). 2005; 81:361-7. 